01

\title{
Применение ИК спектроскопии и метода теории функционала плотности для оценки относительного содержания триглицеридов олеиновой и линолевой кислот в смеси оливкового масла и масла семян подсолнечника
}

\author{
(C) К.В. Березин ${ }^{1}$, К.Н. Дворецкий ${ }^{2,}$, М.Л. Чернавина ${ }^{1}$, А.В. Новоселова ${ }^{1}$, В.В. Нечаев ${ }^{3}$, \\ А.М. Лихтер ${ }^{4}$, И.Т. Шагаутдинова ${ }^{4}$, В.В. Смирнов ${ }^{4}$, Е.М. Антонова ${ }^{5}$, О.Н. Гречухина ${ }^{6}$
}

${ }^{1}$ Саратовский национальный исследовательский государственный университет, 410012 Саратов, Россия

${ }^{2}$ Саратовский государственный медицинский университет,

410012 Саратов, Россия

${ }^{3}$ Саратовский государственный технический университет,

410054 Саратов, Россия

${ }^{4}$ Астраханский государственный университет,

414056 Астрахань, Россия

${ }^{5}$ Астраханский государственный медицинский университет, 414000 Астрахань, Россия

${ }^{6}$ Каспийский институт морского и речного транспорта, 414014 Астрахань, Россия

ฯ e-mail: dcn@yandex.ru

Поступила в редакцию 25.03.2019 г.

В окончательной редакции 25.03.2019 г.

Принята к публикации 12.08.2019 г.

\begin{abstract}
Зарегистрированы ИК спектры пяти образцов масел семян подсолнечника и пяти образцов оливкового масла холодного отжима различных торговых марок в диапазоне $650-3800 \mathrm{~cm}^{-1}$. В рамках методов B3LYP/6-31G(d) построены структурные модели восьми жирных кислот: олеиновой, линолевой, пальмитиновой, стеариновой, альфа-линоленовой, арахидоновой, эйкозапентаеновой и докозагексаеновой, а также триглицеридов первых четырех из вышеописанных кислот. Рассчитаны колебательные волновые числа и интенсивности в ИК спектрах. Используя супермолекулярный подход, проведено моделирование ИК спектров оливкового масла и масла семян подсолнечника. Исследована зависимость интенсивности колебательных полос $v_{\text {экп }}=914 \mathrm{~cm}^{-1}$ и $v_{\text {эксп }}=3009 \mathrm{~cm}^{-1}$ от содержания в маслах триглицеридов олеиновой и линолевой кислот. Исследована зависимость интенсивности этих полос от степени насыщенности жирных кислот. Построены экспериментальная и эмпирические зависимости для оценки относительного содержания триглицеридов олеиновой и линолевой кислот в смеси оливкового масла и масла семян подсолнечника. Обсуждена применимость теории функционала плотности совместно с ИК спектроскопией для определения смесей растительных масел.
\end{abstract}

Ключевые слова: ИК спектроскопия, теория функционала плотности, триглицериды жирных кислот.

DOI: $10.21883 /$ OS.2019.12.48680.127-19

\section{Введение}

В последние годы использование ИК спектроскопии с использованием фурье- преобразования (FTIR) находит применение в качестве аналитического инструмента при анализе пищевых продуктов [1] и, в частности, растительных и животных масел и жиров. В работах [24] с помощью ИК спектроскопии изучался процесс окисления ряда образцов пищевых масел, нагреваемых в конвекционной печи при $70^{\circ} \mathrm{C}$. В работе [5] с помощью ИК спектроскопии изучалось качество соевого масла при его обжарке на $180^{\circ} \mathrm{C}$. В [6] проводился мониторинг степени окисления четырех пищевых масел с помощью ИК спектроскопии. Определение биологически активных добавок в пищевых маслах проводилось в работе [7]. Так, например, с помощью ИК спектроскопии проводится определение транс-ненасыщенности в маслах посредством измерения интенсивности полосы поглощения $967 \mathrm{~cm}^{-1}$, этот метод является стандартизированным IUPAC (1987), AOCS (1989) и AOAC (1990) [2]. Количественный анализ потенциальных примесей оливкового масла с использованием ИК спектроскопии проводился в работе [8]. Определение качества оливкового масла и других масел с применением ИК спектроскопии и использования статистического метода многомерного анализа и метода частичных наименьших квадратов применялся в работах [8-10]. Фальсификация масел в настоящее время является проблемой для пищевой промышленности, особенно для дорогостоящих масел, таких как 
оливковое масло, и существует потребность в быстрых и простых методах обнаружения фальсификации масла. В настоящей работе мы используем ИК спектроскопию с супермолекулярным моделированием [11] спектральных свойств ряда оливковых масел и рафинированных масел семян подсолнечника для определения содержания примеси рафинированного подсолнечного масла в оливковом масле холодного отжима путем оценки относительного содержания в их смеси триглицеридов олеиновой и линолевой кислот.

По экспериментальным данным [12] известно, что в жирнокислотную основу оливкового масла и масла подсолнечника входят олеиновые (омега-9) и линолевые (омега-6) триглицериды, из которых линолевая кислота незаменима, т.е. не синтезируется организмом из других кислот, а попадает в него только с пищей. При составлении правильного рациона питания очень важно соблюдать баланс как между незаменимыми полиненасыщенными кислотами омега-3 и омега-6, так и между полиненасыщенными и мононенасыщенными, из которых олеиновая кислота является самой распространенной. Таким образом, экспресс-анализ жирнокислотного состава наиболее употребляемых в пищевом рационе растительных масел необходим не только для выявления их фальсификации, но и для составления правильного рациона питания.

Настоящая работа является продолжением исследования авторами способов применения колебательной спектроскопии и теории функционала плотности для оценки относительного содержания триглицеридов жирных кислот в смеси растительных масел [13].

\section{Методика и результаты эксперимента}

Экспериментальные исследования проводились на ИК фурье-спектрометре Frontier фирмы Perkin Elmer в диапазоне 650-3800 $\mathrm{cm}^{-1}$. Инфракрасные спектры были сняты на приставке НПВО. Общие условия проведения экспериментов были следующие: атмосферное давление $-762 \mathrm{mmHg}$, температура $-25^{\circ} \mathrm{C}$, относительная влажность - 42\%, разрешение прибора $-0.4 \mathrm{~cm}^{-1}$, режим - 32 scan. Для исследования были выбраны 5 образцов масел семян подсолнечника и 5 образцов оливкового масла, для которых экспериментально определен жирнокислотный состав [14]. Все образцы растительных масел были закуплены в продуктовых магазинах г. Саратова, РФ. Для анализа зависимости интенсивности ИК полос от относительного содержания в смеси масел триглицеридов олеиновой и линолевой жирных кислот дополнительно были зарегистрированы ИК спектры объемных смесей оливкового масла и масла семян подсолнечника (доля каждого масла в смеси варьировалась от 10 до $90 \%$ с шагом 10\%).

Расчеты спектров жирных кислот (олеиновой, линолевой, стеариновой и пальмитиновой) и их триглицеридов проводились методом B3LYP/6-31G(d) по про- грамме [15]. Дополнительно для исследования зависимости интенсивности некоторых ИК полос от степени насыщенности кислот были рассчитаны структуры и ИК спектры четырех жирных кислот, относящихся к классу омега-3: альфа-линоленовой, арахидоновой, эйкозапентаеновой и докозагексаеновой.

Молекулярные модели оливкового масла и масла семян подсолнечника строились на основе четырех моделей триглицеридов жирных кислот (олеиновой, линолевой, пальмитиновой и стеариновой). Содержание этих триглицеридов жирных кислот в моделях устанавливалось таким, чтобы оно соответствовало усредненному значению для пяти исследуемых масел. Затем значения нормировались, чтобы их сумма была равна 100\%, так как содержание в маслах других типов жирных кислот не учитывалось. Таким образом, в модели оливкового масла содержание триглицеридов олеиновой кислоты составило $81.7 \%$, линолевой - 6.3\%, пальмитиновой $9.2 \%$, стеариновой - 2.7\%, а для модели масла семян подсолнечника 19.1, 69.1, 7.2 и 4.6\% соответственно. Теоретическое моделирование процесса фальсификации оливкового масла маслом семян подсолнечника проводилось путем изменения взаимного отношения триглицеридов олеиновой и линолевой кислот с учетом общего изменения содержания насыщенных кислот при переходе от модели оливкового масла к модели масла семян подсолнечника. Теоретические ИК спектры моделей исследуемых масел строились по программе [16]. Полуширина всех лоренцевых контуров задавалась равной $10 \mathrm{~cm}^{-1}$. Для лучшего согласия с экспериментом вычисленные значения колебательных волновых чисел были скорректированы с помощью метода линейного масштабирования частот [17]. Интегральная интенсивность экспериментальных полос определялась путем подсчета количества пикселей в ограниченном снизу контуре при разрешении спектрограммы $600 \mathrm{dpi}$.

\section{Результаты и обсуждение}

Экспериментальные ИК спектры образцов оливкового масла и масла семян подсолнечника показаны на рис. 1. Теоретическая интерпретация экспериментального ИК спектра одного из образцов масла семян подсолнечника представлена в табл. 1. Для нашего исследования в качестве аналитических мы выбрали следующие две полосы в ИК спектре. Первая, $v_{\text {эксп }}=914 \mathrm{~cm}^{-1}$, согласно расчету образована валентным колебанием C-Cсвязей между углеродом $\mathrm{CH}_{2}$-групп и атомами углерода, относящимися к ненасыщенным связям. Вторая, $v_{\text {эксп }}=3009 \mathrm{~cm}^{-1}$, образована валентными С-Н-колебаниями ненасыщенных частей жирнокислотных цепей. Изменение степени ненасыщенности жирнокислотных цепей естественным образом отражается на интенсивности этих полос, что позволяет использовать их для оценки относительного содержания в растительных маслах ненасыщенных кислот. 
$a$

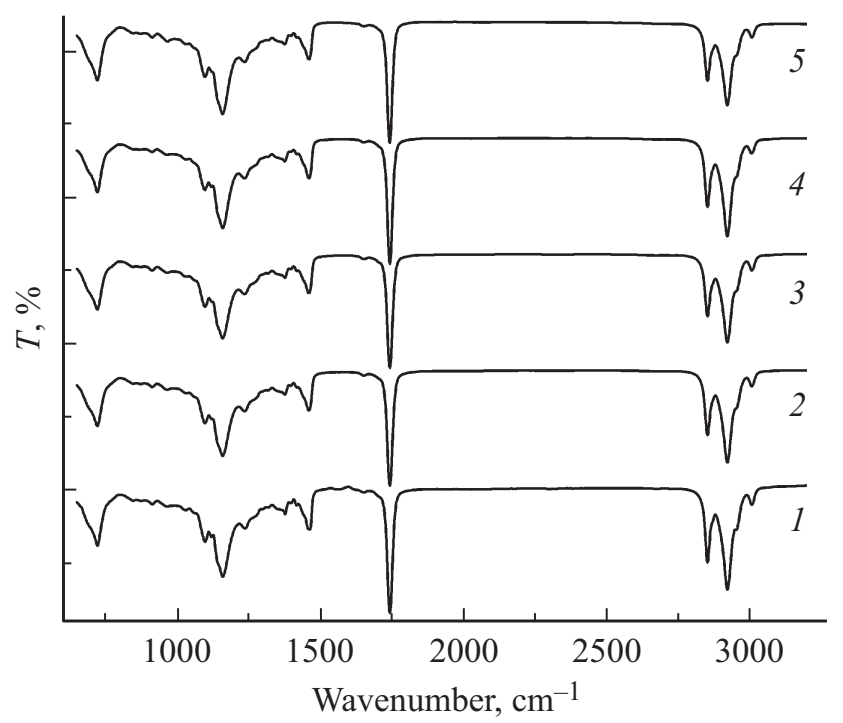

$b$

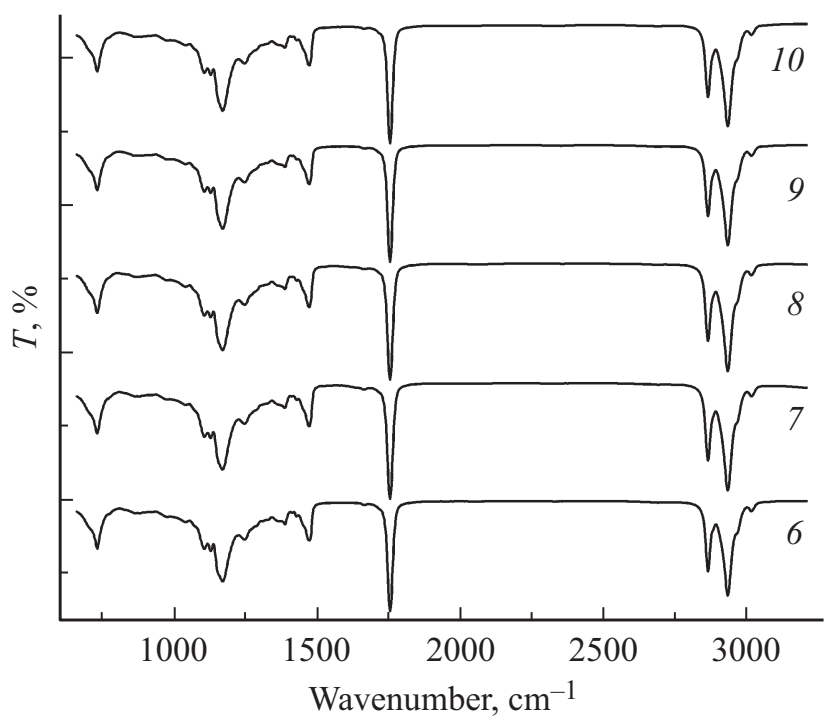

Рис. 1. Экспериментальные ИК спектры масел семян подсолнечника $(a)$ и оливковых масел $(b)$ в области $650-3200 \mathrm{~cm}^{-1}$. Цифрами на графиках обозначены номера образцов масел.
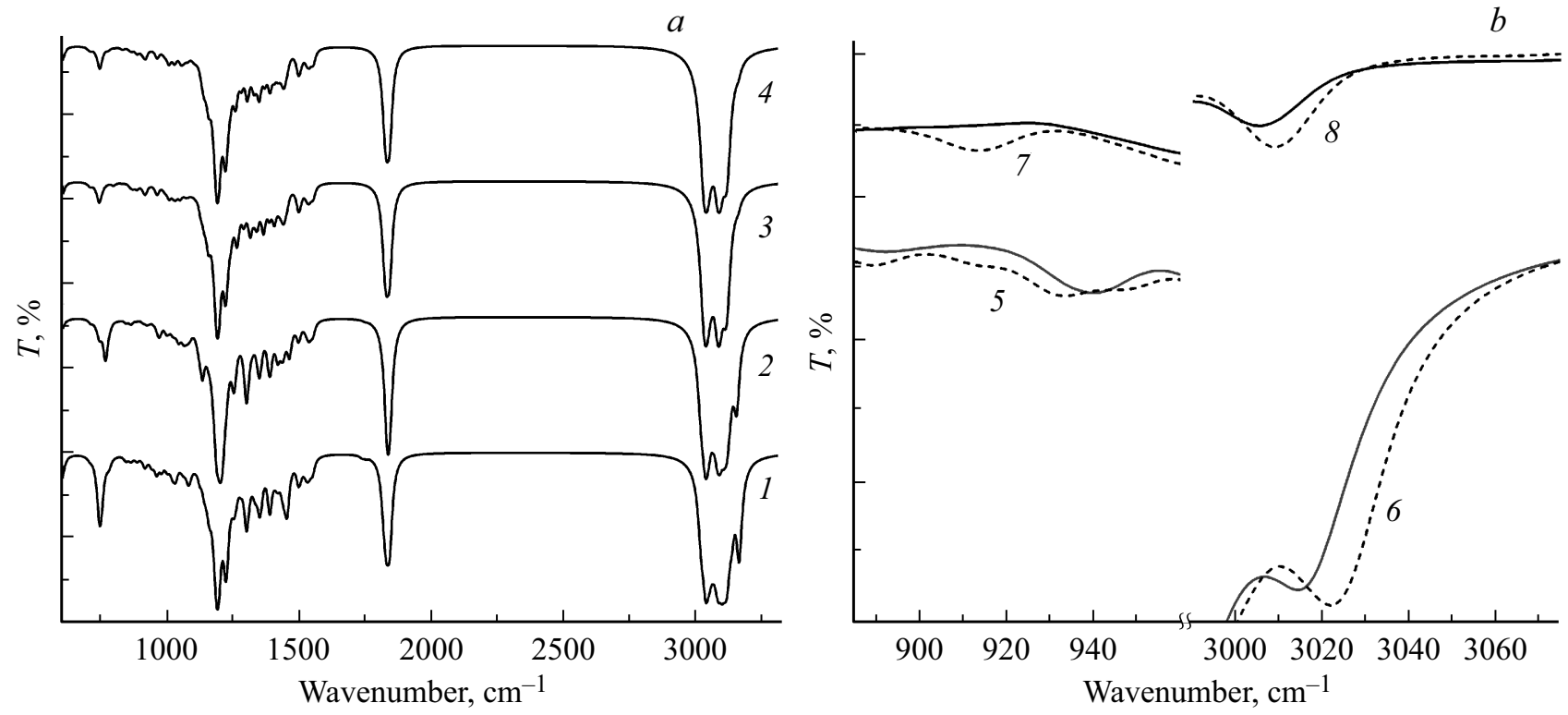

Рис. 2. Теоретические ИК спектры триглицеридов (a) линолевой $(1)$, олеиновой (2), пальмитиновой (3) и стеариновой (4) жирных кислот, а также $(b)$ теоретические $(5,6)$ и экспериментальные полосы $(7,8) v_{\text {эксп }}=914 \mathrm{~cm}^{-1}$ и $v_{\text {эксп }}=3009 \mathrm{~cm}^{-1}$ для оливкового масла (штриховая линия) и масла семян подсолнечника (сплошная линия).

На рис. 2 представлены теоретические ИК спектры триглицеридов линолевой, олеиновой, пальмитиновой и стеариновой жирных кислот, а также сравнение выбранных для анализа экспериментальных и теоретических ИК полос двух типов растительных масел (образцы 3 и 8 ). Как видно из рис. $2, b$, полоса с $v_{\text {эксп }}=914 \mathrm{~cm}^{-1}$, образованная валентными колебаниями C-C-связей между ненасыщенными фрагментами цепей, гораздо сильнее проявляется в спектре подсолнечного масла. Это связано с тем, что интенсивность этой полосы зависит только от концентрации триглицеридов полиненасыщенных кислот, входящих в состав растительных масел (рис. 3,a). Из четырех основных жирных кислот, входящих в состав рассматриваемых растительных масел, эта полоса наблюдается (рис. 3, $a$ ) только у полиненасыщенной линолевой кислоты. Следовательно, наблюдаемое различие в ИК спектрах растительных масел обусловлено тем, что в среднем концентрация линолевой кислоты у масла семян подсолнечника почти в 7 раз больше, чем у оливкового масла. 

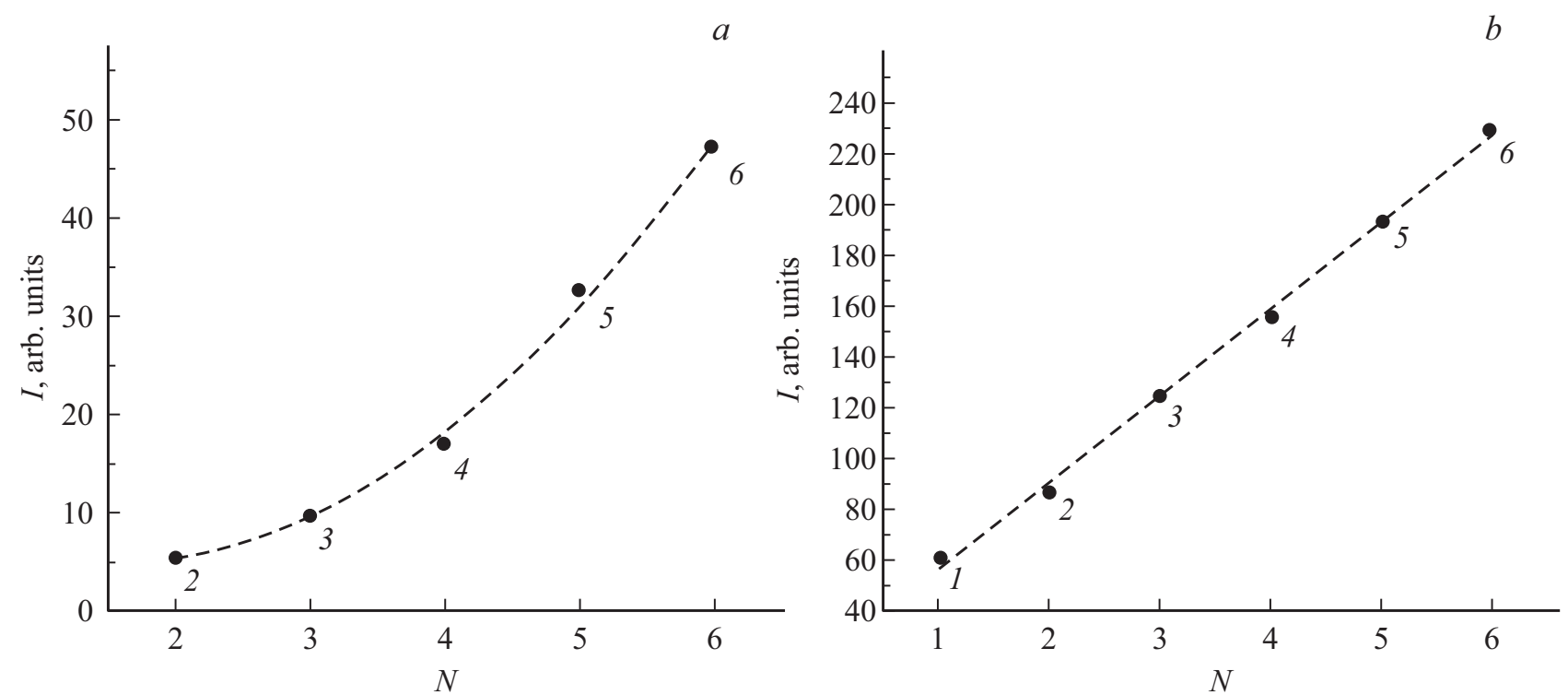

Рис. 3. Теоретические зависимости интенсивностей ИК полос $(a) v_{\text {экп }}=914 \mathrm{~cm}^{-1}$ от числа валентных колебаний С-С-связей, находящихся между ненасыщенными фрагментами цепи, и $(b) v_{\text {эксп }}=3009 \mathrm{~cm}^{-1}$ от числа валентных колебаний связей $\mathrm{C}-\mathrm{H}$, принадлежащих этим фрагментам, рассчитанные методом B3LYP/6-31G(d). Цифрами на графиках обозначены следующие жирные кислоты: олеиновая (1); линолевая (2); $\alpha$-линоленовая (3); арахидоновая (4); эйкозапентаеновая (5) и докозагексаеновая (6).

Вторая полоса с $v_{\text {эксп }}=3009 \mathrm{~cm}^{-1}$ образована валентными $\mathrm{C}-\mathrm{H}$-колебаниями ненасыщенных частей жирнокислотных цепей и, следовательно, проявляется у всех ненасыщенных жирных кислот, входящих в состав растительных масел. На рис. $3, b$ представлены теоретические зависимости интенсивности рассматриваемой ИК полосы от числа колебаний ненасыщенных частей жирнокислотных цепей (валентные колебания связей $\mathrm{CH}$, входящих в состав $\mathrm{C}=\mathrm{C}$-групп). Из рис. $3, b$ видно, что с увеличением степени ненасыщенности жирнокислотной цепи интенсивность этой ИК полосы довольно быстро линейно возрастает.

Для удобства сравнения спектров различных масел между собой интенсивности обеих полос нормировались на интенсивность полосы $v_{\text {эксп }}=1744 \mathrm{~cm}^{-1}$, которая образована валентными колебаниями $\mathrm{C}=\mathrm{O}$-связей карбонильных групп и практически не зависит (рис. 2, $a$ ) от длины жирнокислотных цепей и степени их ненасыщенности.

На рис. 4, $a$ представлены экспериментальные и теоретические зависимости относительной интенсивности полосы с $v_{\text {эсп }}=914 \mathrm{~cm}^{-1}$ от соотношений концентраций олеиновой и линолевой кислот для различных образцов оливкового масла и масла семян подсолнечника, а также для их смесей (образцы 5 и 7). Также из рисунка видно, что теоретическая и экспериментальная зависимости относительной интенсивности для различных смесей растительных масел хорошо описываются логарифмической регрессионной моделью (коэффициент детерминации $R^{2}$ лежит в интервале от 97.3 до $93.8 \%$ ). Для теоретической зависимости эта модель может быть описана уравнением типа $Y=-0.0079 \ln (X)+0.0251$, а для экспериментальной $Y=-0.0055 \ln (X)+0.0144$, где $X$ - отношение концентраций олеиновой и линолевой кислот, $Y$ - отношение интенсивности ИК полосы на частоте $914 \mathrm{~cm}^{-1}$ к интенсивности на частоте $1744 \mathrm{~cm}^{-1}$.

Зависимость между полученными экспериментально интенсивностями ИК полосы с $v_{\text {эксп }}=914 \mathrm{~cm}^{-1}$ и их теоретическими оценками представлена на рис. $4, b$. Из рисунка видно, что эта зависимость хорошо описывается линейной регрессионной моделью (коэффициент линейной корреляции $r=0.99) \quad Y=0.7018 X-0.0032$, где $X$ и $Y$ - теоретические и экспериментальные относительные интенсивности ИК полосы на частоте $v_{\text {эксп }}=914 \mathrm{~cm}^{-1}$. Эту зависимость можно использовать для предварительной оценки результатов эксперимента по регистрации ИК спектра на данной частоте для смесей растительных масел с помощью теоретического моделирования.

Полученная зависимость была использована нами для оценки результатов моделирования эксперимента по смешиванию оливкового масла и масла семян подсолнечника с усредненным жирнокислотным составом (рис. $4, a$ ). Полученная зависимость относительной интенсивности ИК полосы от соотношений концентраций олеиновой и линолевой кислот также хорошо описывается логарифмической регрессионной моделью $Y=-0.0091 \ln (X)+0.0246$ (коэффициент детерминации $R^{2}=99.4 \%$ ). С помощью этой зависимости были оценены результаты эксперимента по смешиванию оливкового масла и масла семян подсолнечника (образцы 3 и 8). Средняя ошибка в определении доли оливкового масла в смеси двух масел составила $6.5 \%$. Эта погреш- 

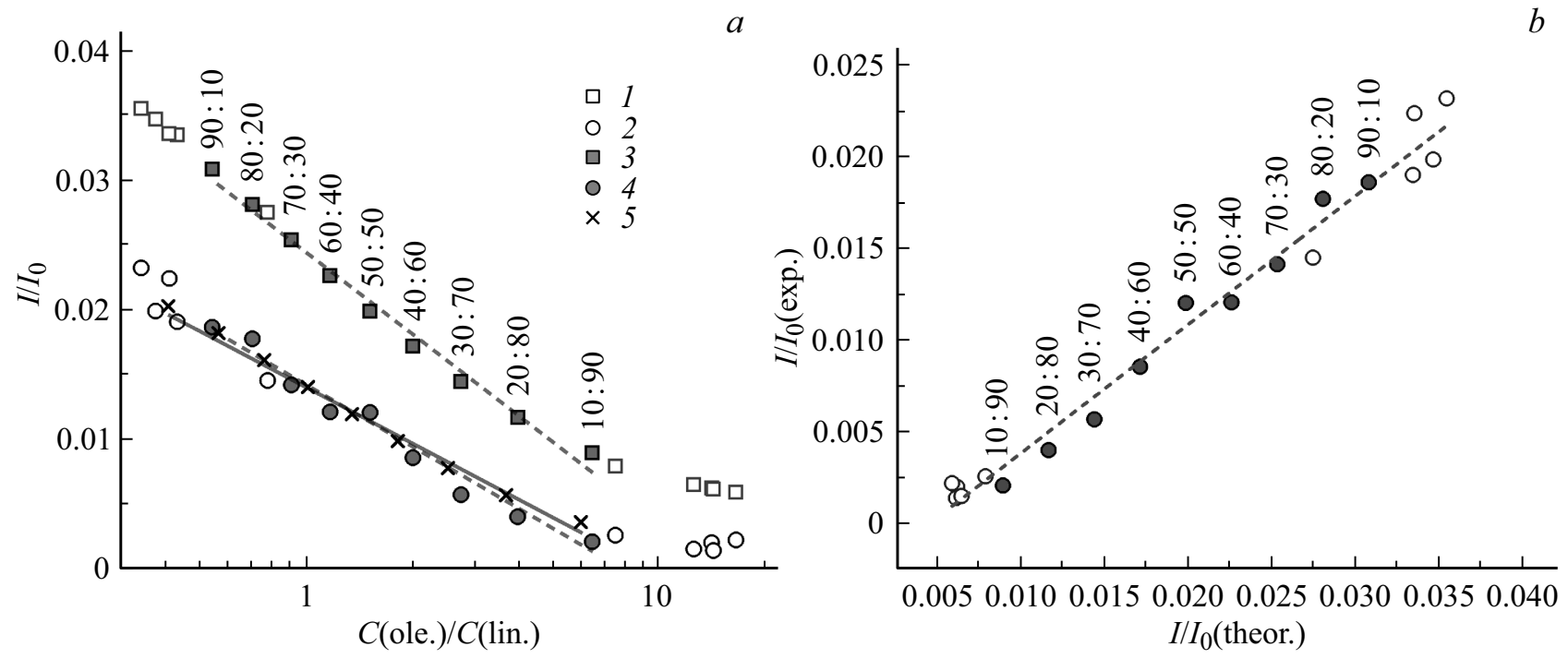

Рис. 4. Зависимость $(a)$ относительной интенсивности двух ИК полос $\left(v_{\text {экпп }}=914 \mathrm{~cm}^{-1}\right.$ к $\left.v_{\text {эксп }}=1744 \mathrm{~cm}^{-1}\right)$, полученных в ходе моделирования ИК спектров 10 образцов растительных масел (1), а также их экспериментальных значений (2) от соотношений концентраций олеиновой и линолевой кислот. Аналогичные теоретические и экспериментальные зависимости для смесей одного из образцов масла семян подсолнечника и оливкового масла обозначены как (3) и (4). Результаты моделирования эксперимента по смешиванию оливкового масла и масла семян подсолнечника с усредненным жирнокислотным составом обозначены как (5). Взаимосвязь $(b)$ между экспериментальными значениями относительной интенсивности ИК полос и полученными в ходе моделирования спектров для образцов оливкового масла (группа светлых точек слева) и масел семян подсолнечника (группа светлых точек справа); темными точками обозначены результаты для смеси одного из образцов масла семян подсолнечника и оливкового масла. Цифрами на графиках дано соотношение концентраций этих масел в смеси, линиями - результаты аппроксимации данных.
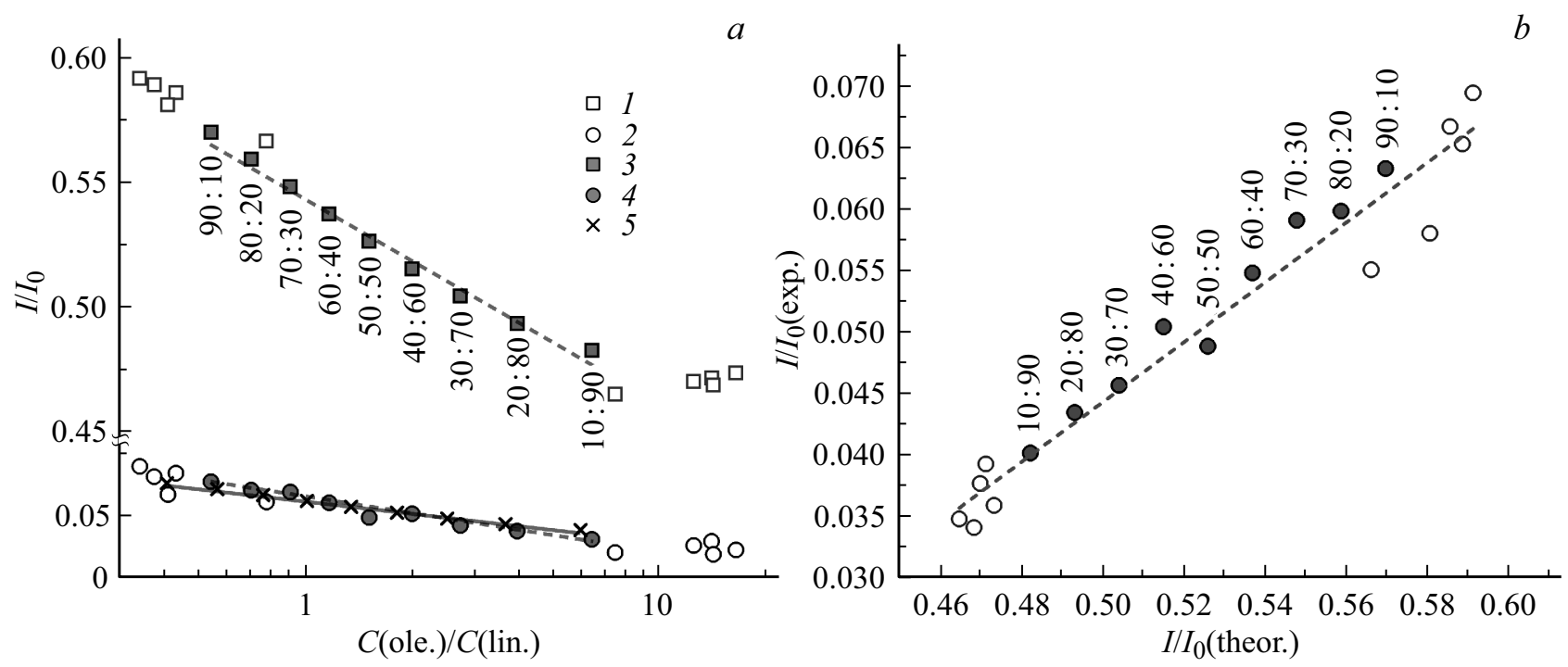

Рис. 5. Зависимость $(a)$ относительной интенсивности двух ИК полос $\left(v_{\text {эксп }}=3009 \mathrm{~cm}^{-1}\right.$ к $\left.v_{\text {экп }}=1744 \mathrm{~cm}^{-1}\right)$, полученных в ходе моделирования ИК спектров 10 образцов растительных масел (1), а также их экспериментальных значений (2) от соотношений концентраций олеиновой и линолевой кислот. Аналогичные теоретические и экспериментальные зависимости для смесей одного из образцов масла семян подсолнечника и оливкового масла обозначены как (3) и (4). Результаты моделирования эксперимента по смешиванию оливкового масла и масла семян подсолнечника с усредненным жирнокислотным составом обозначены как (5). Взаимосвязь $(b)$ между экспериментальными значениями относительной интенсивности ИК полос и полученными в ходе моделирования спектров для образцов оливкового масла (группа светлых точек слева) и масел семян подсолнечника (группа светлых точек справа); темными точками обозначены результаты для смеси одного из образцов масла семян подсолнечника и оливкового масла. Цифрами на графиках дано соотношение концентраций этих масел в смеси, линиями - результаты аппроксимации данных. 
Теоретическая интерпретация экспериментального ИК спектра масла семян подсолнечника (образец номер 3, рис. 1)

\begin{tabular}{|c|c|c|c|}
\hline $\begin{array}{c}\text { Волновое число, } \\
\text { эксперимент, } \mathrm{cm}^{-1}\end{array}$ & $\begin{array}{c}\text { Интенсивность } \\
\text { экспериментальных полос }\end{array}$ & $\begin{array}{c}\text { Волновое число, } \\
\text { теория, } \mathrm{cm}^{-1}\end{array}$ & $\begin{array}{c}\text { Теоретическая } \\
\text { интерпретация }\end{array}$ \\
\hline 3009 & Слабая & 3012 & Валентные C-H-колебания ненасыщенных частей цепей \\
\hline 2954 & Крыло & 2968 & Валентные $\mathrm{C}-\mathrm{H}-к о л е б а н и я ~ \mathrm{CH}_{3}$-групп \\
\hline 2924 & Очень сильная & 2952 & Валентные $\mathrm{C}-\mathrm{H}$-колебания $\mathrm{CH}_{2}$-групп \\
\hline 2854 & Сильная & 2897 & \\
\hline 1744 & Очень сильная & 1767 & Валентные колебания $\mathrm{C}=\mathrm{O}$-связей \\
\hline 1652 & Очень слабая & 1674 & Валентные колебания $\mathrm{C}=\mathrm{C}$-связей \\
\hline 1462 & Средняя & 1475 & Ножничные колебания $\mathrm{CH}_{2}$-групп \\
\hline 1420 & Крыло & 1443 & \\
\hline 1396 & Крыло & & \\
\hline 1376 & Слабая & 1400 & $\begin{array}{c}\text { Маятниковые (плоские) колебания } \mathrm{C}-\mathrm{H}-\text { связей } \\
\text { ненасыщенных фрагментов и } \\
\text { веерные колебания } \mathrm{CH}_{2} \text {-групп }\end{array}$ \\
\hline 1318 & Крыло & 1339 & Веерные колебания $\mathrm{CH}_{2}$-групп \\
\hline 1236 & Слабая & 1255 & Веерные и маятниковые колебания $\mathrm{CH}_{2}$-групп \\
\hline 1160 & Очень сильная & 1151,1181 & Валентные колебания $\mathrm{C}-\mathrm{O}$ глицериновой сшивки \\
\hline 1098 & Слабая & 1121 & Деформационные колебания (угловые) глицериновой сшивки \\
\hline 1034 & Крыло & 1046 & Валентные колебания $\mathrm{C}-\mathrm{C}$-связей цепей \\
\hline 966 & Очень слабая & 994 & Валентные колебания C-C-связей цепей \\
\hline 914 & Очень слабая & 910 & $\begin{array}{l}\text { Валентные колебания C-C-связей } \\
\text { между ненасышенными }\end{array}$ \\
\hline 874 & Очень слабая & 885 & Деформационные колебания цепей \\
\hline 844 & Очень слабая & 857 & Деформационные колебания глицериновой сшивки \\
\hline 722 & Сильная & 719 & $\begin{array}{c}\text { Маятниковые (не плоские) колебания } \mathrm{C}-\mathrm{H}-\text {-вязей } \\
\text { ненасыщенных фрагментов и } \\
\text { маятниковые колебания } \mathrm{CH}_{2}\end{array}$ \\
\hline
\end{tabular}

ность во многом объясняется отличием использованных в эксперименте образцов масел от использованных в регрессионной модели масел с усредненными составами.

Аналогичные результаты для интенсивности ИК полосы с $v_{\text {эксп }}=3009 \mathrm{~cm}^{-1}$ представлены на рис. 5, $a$. Видно, что в отличие от рассмотренной выше полосы с $v_{\text {эксп }}=914 \mathrm{~cm}^{-1}$ наблюдается гораздо большее различие между экспериментальными данными и их теоретическими оценками. Тем не менее видно, что на данной частоте как теоретическая, так и экспериментальная зависимости относительной интенсивности для различных смесей растительных масел также хорошо описывается логарифмической регрессионной моделью (коэффициент детерминации $R^{2}$ лежит в интервале от 98.8 до $95.6 \%$ ). Для теоретической зависимости эта модель может быть описана уравнением типа $Y=-0.0364 \ln (X)+0.544$, а для экспериментальной $Y=-0.00956 \ln (X)+0.0564$, где $X$ - отношение концентраций олеиновой и линолевой кислот, $Y$ - отношение интенсивности полосы на частоте $3009 \mathrm{~cm}^{-1}$ к интенсивности полосы на частоте $1744 \mathrm{~cm}^{-1}$.

Также на рис. 5, $b$ отображена зависимость между полученными экспериментально интенсивностями ИК полосы с $v_{\text {эксп }}=3009 \mathrm{~cm}^{-1}$ и их теоретическими оценками. Видно, что эта зависимость, так же как и для полосы
$914 \mathrm{~cm}^{-1}$, хорошо описывается линейной регрессионной моделью (коэффициент линейной корреляции $r=0.976$ ) $Y=0.2431 X-0.0773$, где $X$ и $Y$ - теоретические и экспериментальные относительные интенсивности ИК полосы на частоте $v_{\text {эксп }}=3009 \mathrm{~cm}^{-1}$. Эту зависимость также можно использовать для оценки результатов эксперимента по регистрации ИК спектра на данной частоте для смесей растительных масел с помощью теоретического моделирования.

На рис. 5, $a$ также представлены результаты моделирования эксперимента по смешиванию оливкового масла и масла семян подсолнечника с усредненным жирнокислотным составом (рис. 5,a). Полученная зависимость относительной интенсивности ИК полосы $3009 \mathrm{~cm}^{-1}$ от соотношений концентраций олеиновой и линолевой кислот хорошо описывается логарифмической регрессионной моделью $Y=-0.0073 \ln (X)+0.0558$ (коэффициент детерминации $R^{2}=99.4 \%$ ). Также с помощью этой зависимости были оценены результаты эксперимента по смешиванию оливкового масла и масла семян подсолнечника (образцы 3 и 8). Средняя ошибка в определении доли оливкового масла в смеси двух масел составила 7.5\%. Эта погрешность также связана с отличием использованных в эксперименте образцов масел от использованных в регрессионной модели масел с усредненными составами. 


\section{Заключение}

Зарегистрированы ИК спектры пяти образцов масел семян подсолнечника и пяти образцов оливкового масла холодного отжима различных торговых марок в диапазоне $650-3800 \mathrm{~cm}^{-1}$. В рамках методов B3LYP/6$31 \mathrm{G}(\mathrm{d})$ построены структурные модели восьми жирных кислот: олеиновой, линолевой, пальмитиновой, стеариновой, альфа-линоленовой, арахидоновой, эйкозапентаеновой и докозагексаеновой, а также триглицеридов первых четырех из вышеупомянутых кислот.

Используя супермолекулярный подход, проведено моделирование колебательного ИК спектра оливкового масла холодного отжима и масла семян подсолнечника. Установлена функциональная связь между интенсивностью двух экспериментально наблюдаемых ИК полос $v_{\text {эксп }}=914 \mathrm{~cm}^{-1}$ и $\nu_{\text {эксп }}=3009 \mathrm{~cm}^{-1}$ от содержания в маслах триглицеридов олеиновой и линолевой кислот, которая хорошо аппроксимируется логарифмической зависимостью.

Проведено экспериментальное и теоретическое моделирование процесса разбавления оливкового масла холодного отжима маслом семян подсолнечника, в результате которого получены функциональные зависимости, которые могут быть использованы на практике как для оценки относительного содержания олеиновых и линолевых кислот в оливковых маслах и маслах семян подсолнечника, так и для оценки доли масла семян подсолнечника в смеси при фальсификации оливкового масла холодного отжима. Средняя ошибка в определении доли оливкового масла в смеси двух масел при использовании спектральных полос $v_{\text {экп }}=914 \mathrm{~cm}^{-1}$ и $v_{\text {эксп }}=3009 \mathrm{~cm}^{-1}$ составила 6.5 и $7.5 \%$ соответственно.

\section{Финансирование работы}

Работа была выполнена при финансовой поддержке в рамках государственных заданий высшим учебным заведениям и научным организациям в сфере научной деятельности, полученных от Минобрнауки (рег. номер 3.9128.2017/БЧ).

\section{Конфликт интересов}

Авторы заявляют, что у них нет конфликта интересов.

\section{Список литературы}

[1] Cozzolino D. // Appl. Spectrosc. Rev. 2012. V. 47. N 7. P. 518. doi 10.1080/05704928.2012.667858

[2] Guillen M.D., Cabo N. // J. Agric. Food Chem. 1999. V. 47. N 2. P. 709. doi $10.1021 / \mathrm{j} 99808123$

[3] Guillen M.D., Cabo N. // J. Sci. Food Agric. 2000. V. 80. N 14. P. 2028. doi 10.1002/1097-0010(200011)80:14<2028::AIDJSFA713>3.0.CO;2-4

[4] Guillen M.D., Cabo N. // Food Chem. 2002. V. 77. N 4. P. 503. doi 10.1016/S0308-8146(01)00371-5
[5] Goburdhun D., Jhaumeer-Laulloo S.B., Musruck R. // Int. J. Food Sci. 2001. V. 52. N 1. P. 31. doi 10.1080/09637480020027183

[6] Russin T., van de Voort F.R. // J. Am. Oil Chem. Soc. 2004. V. 81. N 2. C. 111. doi 10.1007/s11744-004-0867-x

[7] Ozen B.F., Weiss I., Mauer L.J. // J. Agric. Food Chem. 2003. V. 51. N 20. P. 5871. doi $10.1021 / \mathrm{jf034245 \textrm {h }}$

[8] Lai Y.W., Kemsley E.K., Wilson R.H. // Food Chem. 1995. V. 53. N 1. P. 95. doi 10.1016/0308-8146(95)95793-6

[9] Tay A., Singh R.K., Krishnan S.S., Gore J.P. // Lebensm.-Wiss. u.-Technol. 2002. V. 35. N 1. P. 99. doi 10.1006/fstl.2001.0864

[10] Ozen B.F., Mauer L.J. // J. Agric. Food Chem. 2002. V. 50. N 14. P. 3898. doi $10.1021 / \mathrm{j} 0201834$

[11] Березин К.В., Шагаутдинова И.Т., Чернавина М.Л., Новоселова А.В., Дворецкий К.Н., Лихтер А.М. // Опт. и спектр. 2017. Т. 123. № 3. С. 472; Berezin K.V, Shagautdinova I.T., Chernavina M.L., Novoselova A.V., Dvoretskii K.N., Likhter A.M. // Opt. Spectrosc. 2017. V. 123. N 3. P. 495. doi 10.1134/S0030400X17090089

[12] Кодекс Алиментариус. Жиры, масла и производные продукты. М.: Весь Мир, 2007. 68 с.

[13] Березин К.В., Дворецкий К.Н., Чернавина М.Л., Новоселова А.В., Нечаев В.В., Антонова Е.М., Шагаутдинова И.Т., Лихтер А.М. // Опт. и спектр. 2018. Т. 125. B. 9. C. 297; Berezin K.V., Dvoretskii K.N., Chernavina M.L., Novoselova A.V., Nechaev V.V., Antonova E.M., Shagautdinova I.T., Likhter A.M. // Opt. Spectrosc. 2018. V. 125. N 3. P. 311. doi 10.1134/S0030400X18090059

[14] [Электронный ресурс] Режим доступа: https://roscontrol.com/category/produkti/rastitelnoe_maslo/

[15] Frisch M.J., Trucks G.W., Schlegel H.B. et al. Gaussian09, Revision A.02. Pittsburgh PA: Gaussian, Inc. 2009.

[16] Файбель А.Б., Березин К.В., Нечаев В.В. Программа для моделирования и визуализации колебательных ИК и КР спектров по данным квантово-механических расчетов. Проблемы оптической физики. Саратов: Изд-во ГосУНЦ „Колледж“, 2003. С. 74.

[17] Березин К.В., Нечаев В.В., Кривохижина Т.В. // Опт. и спектр. 2003. T. 94. № 3. C. 398; Berezin K.V., Nechaev V.V., Krivokhizhina T.V. // Opt. Spectrosc. 2003. V. 94. N 3. P. 357. doi 10.1134/1.1563679 